University of Wollongong

Research Online

Faculty of Law, Humanities and the Arts Papers (Archive)

Faculty of Arts, Social Sciences \& Humanities

$1-1-2015$

Re-routing Empire? Steam-age circulations and the making of an Anglo

Pacific, c.1850-90

Frances Steel

University of Wollongong, fsteel@uow.edu.au

Follow this and additional works at: https://ro.uow.edu.au/lhapapers

Part of the Arts and Humanities Commons, and the Law Commons

Research Online is the open access institutional repository for the University of Wollongong. For further information contact the UOW Library: research-pubs@uow.edu.au 


\title{
Re-routing Empire? Steam-age circulations and the making of an Anglo Pacific, c. $1850-90$
}

\author{
Abstract \\ The introduction of steam not only enhanced Australia's transport links within the empire. It also altered \\ attitudes towards the feasibility and desirability of transpacific connectivities, and brought new \\ prominence to the Pacific-orientations of Australia's eastern colonies. By envisioning steam-age \\ connections across the Pacific, first to Panama and then to San Francisco, Australia sought to imagine \\ and situate itself in a transpacific sphere. The routes shaped cultural sensibilities and political ideologies \\ across the Pacific, expressed in affinities and allegiances between Australia and North America. This \\ article examines transpacific steam from the mid- to the late nineteenth century, a fractured and \\ indeterminate period which nevertheless laid the ground for Australia's sense of itself as an autonomous \\ white nation, relating across the Pacific and within a wider Anglo world beyond Britain and empire.

\section{Disciplines} \\ Arts and Humanities | Law

\section{Publication Details} \\ Steel, F. (2015). Re-routing Empire? Steam-age circulations and the making of an Anglo Pacific, \\ c.1850-90. Australian Historical Studies, 46 (3), 356-373.
}




\title{
Re-Routing Empire? Steam-Age Circulations and the Making of an Anglo Pacific, c. $1850-90$
}

\author{
Frances Steel
}

\begin{abstract}
:
The introduction of steam not only enhanced Australia's transport links within the empire. It also altered attitudes towards the feasibility and desirability of transpacific connectivities, and brought new prominence to the Pacific-orientations of Australia's eastern colonies. By envisioning steam-age connections across the Pacific, first to Panama and then to San Francisco, Australia sought to imagine and situate itself in a transpacific sphere. The routes shaped cultural sensibilities and political ideologies across the Pacific, expressed in affinities and allegiances between Australia and North America. This article examines transpacific steam from the mid to the late nineteenth century, a fractured and indeterminate period which nevertheless laid the ground for Australia's sense of itself as an autonomous white nation, relating across the Pacific and within a wider Anglo world beyond Britain and empire.
\end{abstract}

In Australian history the sea has been an 'ambivalent force', a medium of connection and isolation. ${ }^{1}$ Histories of oceanic connection are themselves shifting and dynamic, expressive of Australia's changing cultural locations. By the mid-nineteenth century, the established sea route between Great Britain and the Australian colonies via the Cape of Good Hope, which passed through the 'stormiest and dangerous seas on the globe', epitomised an earlier, precarious era of imperial mobility. Associated with exile, London's Athenaeum dismissed it as a route fit 'only for convicts, midshipmen, and colonial office dispatches'. In a world of ‘electric telegraphs, express trains and fast steamers', new cultures of imperial mobility and newly mobile people required new tracks. An alternate route via Panama and across the Pacific presented a 'safe, direct, and easy route'. It would also, unlike the Cape route, bring to New South Wales' shores, 'widely-spreading Atlantic and Pacific communications, and mails, treasure, merchandize, and passenger traffic'. ${ }^{2}$

In this article I suggest how by envisioning steam-age connections across the Pacific, first to Panama and then to San Francisco, Australia sought to imagine and situate itself in a 
transpacific sphere. Such routes became a medium for building on and reshaping regional geographies that arose in the age of sail. From the beginnings of European settlement, colonies in eastern Australia understood themselves as part of the Pacific, an orientation that mid-century gold rushes in California, Melbourne and British Columbia reinforced as they plotted a Pacific World encircled by providential white settler colonies. Steam built upon and extended these connections and flows, allowing affinities to develop between Australia and North America. Crucially, new routes shaped cultural and political ideologies and sensibilities, with the racialised mid-century ideals of an 'expanding Anglo-Saxon polity around the Pacific' and its imagined global destinies gaining new prominence and heightened promise. ${ }^{3}$ Steam moulded enduring ways of identifying and relating within and across the Pacific, and within but also beyond Britain and empire. Regional affinities along imagined lines of race would come to underpin the constitution of modern political subjectivities in New World communities around what became known as the Pacific Rim. ${ }^{4}$

Australia's Pacific pasts were not uniformly or evenly shared. The continental landmass looked out over many seas. Transpacific pathways were naturally of most significance to settlements along the eastern seaboard - principally New South Wales (NSW), but also Victoria and Queensland - and their relations with New Zealand. ${ }^{5}$ The push to bridge the Pacific in this way has been explored as a key dimension of Tasman World history - 'chiefly as a phase of Australia-New Zealand relations', given the lengthy intercolonial negotiations and frictions this generated, particularly in the early 1870 s. $^{6} \mathrm{I}$ revisit these frictions, but in order to widen the angle of vision. Following Kate Hunter, who argues that the scholarly attention to the Tasman World might be moved 'to new territories', and Damon Salesa, who urges Antipodeans historians to take the heed of Atlanticists and be 'coaxed out to sea', we might do more to place regional perspectives in wider transoceanic frames. ${ }^{7}$ Localising the transpacific around Australasia is a valuable endeavour that requires 
also to be contextualised through a closer understanding of how steam was simultaneously stretching and transforming colonial imaginaries of the Pacific and the United States in other directions. I seek, therefore, to highlight how the prospect of connections to North America played into the ways in which Australian colonies (predominantly in the east) sought to envision and define their Pacific domain.

I begin this article by tracing the development of transpacific histories, charting key themes and concerns, and areas less well-developed in the literature, in order to position the contribution of my study of transoceanic connectivity. The body of the article examines the visions and logics that early steam-age flows between strategic maritime hubs in the Pacific defined, channelled, or sustained - first, in a more tentative era of connectivity from the midnineteenth century between Sydney and Panama, then shifting north to San Francisco from 1870. I conclude my discussion in the late 1880 s, when the prospect of bridging Australia and Canada demanded a new series of negotiations and adjustments in this transpacific field. ${ }^{8}$

\section{Writing transpacific histories}

The transpacific, which I define here simply as the networks and exchanges that linked people and places across the Pacific, encompasses material and physical circulations as well as imaginative geographies. It holds many meanings and has been deployed in different ways in different contexts and periods. Speaking generally, transpacific histories plot the growing engagement and consolidation of imperial power in the region, beginning with the Spanish galleon trade in the sixteenth century. These projects did not newly 'mobilise' the Pacific, given the deep and enduring indigenous histories of movement and connections. As narrowed corridors of passage, such networks obscured or circumvented Islander zones of connectivity. However, while the risk of mistaking their visibility for reach and impact cannot be ignored, 
these networks were also formative of settler colonial imaginaries of the Pacific and the Australian colonies' place within them.

Looking out from Australia, transpacific histories have encompassed predominantly the United States. Gordon Greenwood's, Early American-Australian Relations (1944) was one of the earliest histories to plot these connections. In his foreword, Stephen H. Roberts (himself the author of the 1927 Population Problems of the Pacific) referred to Greenwood's role in the 'revival and extension of Australian historical studies which has been such a marked feature of the growing stress on the Pacific zone in the last few years'. ${ }^{9}$ Insofar as we might read this as embedding Australian history-writing within the Pacific_-rather than a simple nod to Australia's geographical location literally in the Pacific_-this revival and extension was arguably short-lived. A string of synoptic histories of Australia-United States relations followed in the early 1970s, emphasising themes of trade, diplomacy and defence. Here the 'Pacific zone' figured more as an empty place-holder between two continents rather than an active mediating space. ${ }^{10}$ These contributions were not aligned with the islandcentred Pacific History developing at about the same time under J.W. Davidson's leadership at the Australian National University. Davidson rejected overarching frames of European imperial expansion narrated from distant metropolitan capitals, for a focus on local 'multicultural situations'. ${ }^{11}$ Such scholarship had, however, relatively little to say about oceanspanning engagements, Oskar Spate's magisterial three-volume The Pacific since Magellan notwithstanding. ${ }^{12}$

Meanwhile, when viewed from the North American coastline, transpacific imaginaries were oriented differently. Expanding its influence rapidly westwards in the nineteenth century, the Pacific was the next arena of expansion for American imperial power, rather than a medium of connection to colonial settlements in Australia. ${ }^{13}$ The 'trans' in the transpacific was easily conflated with the United States (i.e. the 'American Pacific'). Such 
echoes continued to resonate in late-twentieth-century framings of the 'Pacific Rim' and the 'Asia Pacific', terms that, according to some historians, described America's geopolitical and strategic alignments with the most powerful Asian states, the flow of transnational capital between them, and ideologies of capitalist development heavily complicit with past conflicts and ongoing militarisation. ${ }^{14}$ In such renderings, the transpacific serves to undergird and reinforce 'big power' political and economic agendas, but especially the regional hegemony of the United States.

Proponents of 'a more progressive transpacific optic' challenge such asymmetrical and imperialist mappings and, in encompassing Asia and the Americas, seek to 'restore the Pacific as a shared space of diverse traffics', including of people, labour, cultures and ideas. ${ }^{15}$ This creates conceptual space for themes of resistance and counter-hegemonic alignments. Janet Hoskins and Viet Thanh Nguyen highlight 'alternate narratives' generated out of 'oppositional localism', referring to alliances between subjugated and marginalised peoples. ${ }^{16}$ Editors of the recent 'Conversations on Transpacific History' in the Pacific Historical Review, similarly propose 'a more inclusive, complex and multifaceted analysis' than exhibited in studies grounded in international relations and economic development. They highlight 'a new kind of multidirectional, multilayered, and multisited transpacific history', and a socially and culturally informed 'people's history of the transpacific'. ${ }^{17}$

Approaches to the 'borderlands' of the Pacific Northwest also plot a revisionist history. Kornel Chang locates the Northwest not simply at the dividing line between America and Canada, but within transpacific and imperial histories. Asian as well as British and American engagements and agency shaped this region. Exploring the convergence of networks at Vancouver and Seattle, he probes the 'duelling impulses' of visions of prosperous futures in Asian markets and the hardening of borders against Asian people. Within this 'world in motion amidst a world of borders', Chang also looks to the ways in 
which transpacific ties were mobilised by communities from below for various ends. ${ }^{18}$ Similarly, Henry Yu attends to 'arrhythmia' - the 'unsteady beat of movement and stoppage' - in transpacific history, as North American borders grew progressively more hostile to people of Asian descent. He maps mobility across a wider spatial canvas, arguing that it cannot be enclosed around transpacific flows. The mass movement of Chinese and then Japanese to the Pacific Northwest was interlocked with migrations from the Atlantic to the Pacific coasts of the United States and Canada. It was here that the imagined geographies of much larger entities—a 'Cantonese Pacific' and 'white civilisation'—collided, the latter promoted as a transcolonial Anglo-Saxon 'Oceania' by high-profile travelling empire writers, such as the British parliamentarian Charles Dilke and the historian and novelist James Anthony Froude. ${ }^{19}$

Read together, migration and the formation of diasporas animates much of this revisionist work. But what of transpacific connections that were not in the first instance migratory? Nor 'grounded in imaginations of the Pacific as a border between East and West' ${ }^{20}$ Just as world and global histories frequently bypass the Pacific, perceiving it as a barrier to exchange or not yielding the sort of dense, integrative flows more characteristic of the Indian and Atlantic oceans, so too are some transpacific connections and relationships afforded more visibility than others on the basis of traffic density and volume. ${ }^{21}$ In this article I foreground the linkages - empirically 'thin' in traffic in people and goods when compared to the North Pacific, but ideologically and culturally 'thick' - between Sydney, Panama, and San Francisco. My aim is not to diminish Asia in transpacific history, nor reinscribe the "pulling power' of America, but instead to trace Australia's imagined broader locations in the Pacific, including in its imperial and racial contexts.

Even as transpacific studies increasingly emphasise oceanic traffic, mobility and circulation, they remain anchored at the rim and the 'endpoints' of intercultural engagement 
and power. I aim to recentre transoceanic networks within the transpacific frame. If 'connectedness runs through Pacific histories', as Matt Matsuda recently stresses, how were connections envisaged and then made to work, how were they mobilised, and how did they change over time? ${ }^{22}$ By attending to such questions, I argue, we are better able to conceive of the fluid, shifting boundaries and cultural imaginaries of the Pacific World, to thereby revisit the Pacific as a site of contestation about Australia's location and destinies, and Australia as a site of Pacific connectedness.

\section{Beyond the Asian Empire? Sydney to Panama}

The vital role of shipping for holding the British empire together is well known. The coming of steam propulsion offered new openings and possibilities. Its immediate promise seemed of most import to communications between the Australian colonies and Britain. Proposals for the introduction of steam, aired first in public meetings in London and Sydney in 1846, presented six different routes, although three were most prominent: following the established sailing route across the Indian Ocean via the Cape of Good Hope; two branch lines from Suez - one via Singapore, the Torres Strait, and northern Australia, the other via Aden, Ceylon and southern Australia; and a route via Panama and across the Pacific. Each route carried different implications for colonial ports and their general orientation towards one another and towards the waters surrounding them. Discussing their respective merits in a letter to Earl Grey of the Colonial Office in 1848, the Sydney trader Adam Bogue addressed the Pacific route first only to roundly dismiss it. The prospective refuelling stops nearest a line drawn between Sydney and Panama were the Marquesas Islands, Tahiti and the Galapagos Islands. Coal shipments to any of these sites would be expensive and difficult. When compared to the Indian Ocean routes, the freighting of coal 'on purpose', Bogue stressed, was a significant deterrent, as was Britain's likely dependence on island ports controlled by France. ${ }^{23}$ 
Metropolitan observers agreed, and in 1852 following the recommendation of a Select Committee of the House of Commons, the British Admiralty awarded a contract for a steamship service to Australia via the Cape of Good Hope. It also supported an additional connection, an extension of the India route branching off at Ceylon to Sydney via Albany and Melbourne.

Developments beyond empire imparted new urgency to the question of steam navigation across the Pacific. The discovery of gold in California at mid-century combined with America's westward expansion created an unprecedented demand for rapid transit to San Francisco. This centred first on securing a shorter route from New York than via Cape Horn, redirecting attention to the narrow isthmus that separated the Atlantic from the Pacific. A steamship service from Panama to San Francisco was quickly favoured, reducing the strategic importance of the Cape highway. ${ }^{24}$

Panama's elevation as an international crossroads through the fortuitous 'combination of steam and gold', not only reconfigured mobilities along the North American coast, but also appeared to be working an 'astounding' change 'in all the countries of the Antipodes and those watered by the Pacific ocean'. ${ }^{25}$ Panama was a hinge through which the Australasian colonies might imagine a range of exchanges, connecting from there to North and South America and the West Indies. A number of schemes were discussed and a newly-chartered firm went so far as to set up coal stocks at Panama, Tahiti, Wellington and Sydney, but in 1854 the shipping demands of the Crimean War interrupted its plans. ${ }^{26}$ A trial voyage of another operator registered an estimated loss of $£ 10,000$. In an unfortunate irony, Bogue who was a passenger on this voyage, died during the transit across the Isthmus of Panama. ${ }^{27}$ No repeat voyages were made.

A rising tide of colonial dissatisfaction with the Admiralty routes, which by the late 1850s were reduced to one service (of an average sixty-four days) via Suez under the 
monopoly of the premier imperial firm, Peninsular \& Oriental Steam Navigation Company $(\mathrm{P} \& \mathrm{O})$, fuelled advocacy of the Panama route as an additional or complementary service. This was urged with particular force in NSW which, as liberal politician Henry Parkes emphasised to the colony's Legislative Assembly in 1858, was put 'at a permanent disadvantage in relation to the Southern colonies' from being 'the last place of intercourse in the Australian system' on the Suez route. This would remain an enduring source of friction in intercolonial discussions of mail subsidies for years to come. ${ }^{28}$

Parkes also advocated new routes on 'different and far higher grounds, affecting the future character and comparative greatness of the country'. The Suez route not only marginalised NSW, but prioritised 'Imperial policy' in the East and metropolitan over colonial interests. They had 'very little of social affinity' with Asiatic countries, which were of value only for their tea, spices and sugar. The same objections would not apply to a transpacific route. Not only did it connect the Australian colonies with like-minded communities in New Zealand and other islands in the Pacific being settled by Europeans, but for Parkes the prospect of closer connection with the United States held an unrivalled affirming and progressive power:

This highway across the Pacific seemed pointed out as by the hand of Providence to give them priority of connexion with other countries - other countries, too, where the grand experiment of founding new empires with a common origin and a common destiny, was going on. Those lands must be the teachers of this, for in no other part of the world were English liberty and English commerce transplanted to work out the ends of English civilisation on a new soil. $^{29}$

Parkes' advocacy struck a chord with the NSW Legislative Assembly and although the Imperial Government made a conditional promise to support it, the American Civil War prevented any progress in that direction. A Panama service finally opened in 1866 (with 
subsidy support from only NSW and New Zealand). ${ }^{30}$ Yet this service lasted only two years as a shortage of passengers and freight, along with a reliance on inefficient and unsuitable ships, forced it to close. These unfavourable results represented a slippage between imagined desires and material realities, the route far less in demand than initially envisaged.

\section{'A large and federal view': Reorienting Australia, 1870-72}

Imperial communications became more efficient, rapid, and expansive in the wake of the completion of the Suez Canal in 1869. The canal promoted the ascendency of steamships over sail. The shortened passage between Britain and Asia meant ships required less coal, lower running expenses, and more space for ships to carry cargo. Held to be emblematic as a threshold between Britain and its colonial dominions and a vital 'imperial relay station', the canal 'recalibrated the geography of empire'. ${ }^{31}$ The completion of the Pacific Railway to San Francisco only a few months earlier recalibrated space in another direction, and raised other visions of 'relay' and connectivity. It promoted the unification of the continent from the Atlantic to the Pacific coasts, and seemed to offer promise as an 'international highway', connecting the United States to the world. ${ }^{32}$ Whereas the American continent once stood as a barrier between Australia and Great Britain, San Francisco now 'lies almost on a direct line' between them, the Alta California celebrated. ${ }^{33}$

Route schemes from Sydney now centred on San Francisco as a west coast terminus, displacing Panama's former centrality. Panama had the reputation of an unhealthy and uncomfortable port. Ships' mail agents and passengers decried the town's 'depravity'. ${ }^{34}$ San Francisco was 'the very opposite', and an overland journey across the United States a 'pleasure trip' when compared to coaling at St Thomas (in the Danish West Indies). ${ }^{35}$ Warming to the theme, Sydney's Empire cast Panama as being 'in the hands of one of those miserable Spanish American republics ... doomed to ... a revolution about once a year'. Its 
'fiscal and commercial affairs' were also of the 'most oppressive and obstructive character', and at odds with the political and cultural affinities of the Anglo world. ${ }^{36}$

Shared imaginaries and histories of exchange also invested this network as more fitting and appropriate: as the Illustrated Sydney News related, California afforded Americans 'their first opportunity of showing their capacity as colonists', and like eastern Australia, it was a frontier settlement remade by gold. ${ }^{37} \mathrm{~A}$ shared colonial mentality found expression in aesthetic preferences, architecture, and other cultural forms. ${ }^{38}$ The landscape and climate were not dissimilar. A common acclimatisation movement to stimulate agricultural productivity in the immediate post-gold years also led to a well-documented exchange in 'ideas, plants, insects, personnel, technology, and dreams'. ${ }^{39}$ Beyond the colonial frontier there was a longer history of traffic between the two continents. People had found their way across the ocean from the late eighteenth century through maritime trades, notably whaling, or along an emerging 'Pacific circuit' of American travelling entertainers. ${ }^{40}$ A transpacific imaginary was also founded on a commerce largely carried by sail. This originated in east coast ports of New York and Boston, entering the Pacific around Cape Horn, with up to twenty ships trading annually to Sydney and Melbourne by the late 1860 s. $^{41}$ The California gold rush further expanded Pacific trade. ${ }^{42}$ Steam offered the promise of reinforcing such connections and aspirations.

Along this more northern Pacific crossing between Australia and San Francisco were a number of island groups_-Fiji, Samoa and Hawai 'i—which seemed obvious choices as coaling stations and ports of call. Unlike the Panama route, which had no prospects of 'intermediate trade', these islands were 'already in commercial correspondence' with the terminal ports and appeared to offer 'inducements' such as presented 'to no other first-class steamer line' ${ }^{43}$ In Fiji the unchecked extension of British and American settler influence was generating debate, yet route promoters found room for optimism in Melbourne's 'virtual 
pledge' to the island group, and the 'prospect of a large American colony' being established there. ${ }^{44}$ The colonial press enthused over the growing export trade in Hawai 'i and held up American commercial enterprise as worthy of emulation.

The reluctance of English shipping companies to venture beyond the Indian and Atlantic oceans also seemed to offer an opportunity to develop colonial resources. Yet establishing shipping operations in the Pacific presented formidable challenges, requiring new partnerships and collaborative ventures. Most of the prominent early figures, such as Hayden Hezekiah Hall and William H. Webb, were American entrepreneurs whose involvement exemplified the American application of individual skills and talent, rather than capital, to new industries on European imperial peripheries. ${ }^{45}$ Their operations were typically fragile and short-lived, as neither the individual colonies nor businessmen-financiers were willing to make long-term commitments or investments. Throughout the early 1870s, undercapitalised operations and the use of unsuitable vessels chartered from other trades by 'phantom' companies and entrepreneurs who 'did not own a ship', hampered reliability and efficiency, and led to what some contemporaries decried as a 'strange mania for insolvency, ${ }^{46}$

In contrast to the Indian Ocean with the central impulse and relative coherence of Britain's Asian empire behind it, Australia's transpacific destinies remained at the mercy of intercolonial divisions and rivalries. New Zealand needed the route most and took the lead in subsidising a service from 1870. Political will was fractured along Australia's eastern seaboard. Interest in proposals for shipping subsidies was not lacking among leading commercial figures and opinion-makers in Victoria and Queensland, and to a lesser extent South Australia and Tasmania. But only NSW granted direct subsidies. With the P\&O's Suez contract due for renewal in 1873 , the early 1870 s were marked by continued commentary and debate about the respective merits of mail route options. The negotiations and debates-mail 
'derangements' by one account-were intricate and involved, but offered new openings to the colonies to reimagine their connection with the United States. ${ }^{47}$

New South Wales appeared to have the most to gain from a transpacific route, yet from some outlooks Melbourne was its more obvious Australian terminus: 'Melbourne stands at one extremity of a broken circle and San Francisco at the other. Their union will make a perfect circle' ${ }^{48}$ The gold rush made for a shared history and gave California and Victoria their twin reputations as exploding 'Anglo-Wests'. ${ }^{49}$ For the Australasian, Victoria had a 'very near and distinct interest' in the completion of the Pacific Railway because it afforded greater intimacy with 'our natural friends and allies'. Given that 'the circumstances and the wants of the two countries' were so alike, a Pacific route would also enable Victoria to profit from developments in America. ${ }^{50}$ Queensland was also positive about increased communication and commercial intercourse with the US, the Brisbane Courier commending the American 'spirit of enterprise' in railroad construction and the prospect of its transoceanic extension. $^{51}$

By now in some personal financial difficulty and working as an agent for Hayden Hall, in 1871 Parkes toured Queensland, Victoria, South Australia and Tasmania to recruit support and urge governments and public bodies to take 'a large and federal view' of the Pacific route. Parkes 'closely identified' the route with 'Australian progress' linked intimately to a global political-cultural vision embracing the empire but also reaching beyond it. The Pacific route was the 'only route possible that will unite in one short chain of unbroken intercourse all the great English-speaking communities ... the future propelling power of the world' ${ }^{52}$ His endeavours received a qualified welcome, the Australasian for instance endorsing the route's advantages, especially as 'any intelligent colonist' would pick up more information useful to a new country than possible if travelling via Egypt, while sounding a note of caution about deeper US influence on the Australian 'national character'. 
It advised Parkes to temper his enthusiasm for this particular 'benefit', for Australians preferred to retain 'their English type in the main'.53

Independently of Hall and accompanied by William Webb, the New Zealand Postmaster General Julius Vogel came calling the following year to drum up support for its transpacific service. Melbourne's commercial leaders hosted a dinner in Webb's honour which concluded with a toast to 'Perpetual Friendship to the Anglo-Saxon Race throughout the World' ${ }^{54}$ Promotion and publicity for these and similar commercial ventures served as rhetorical opportunities reinforcing 'overt and self-conscious' notions of an Anglo Saxon 'Oceania'. ${ }^{55}$ Debating the subsidy proposal in Victoria's legislative assembly, Premier and Irish Nationalist Charles Duffy stressed that 'the American people, like ourselves, are living in a new country, under democratic institutions, and we have much to learn from them' ${ }^{56}$ Ultimately, as in Queensland, Victorian leaders found better mail connections via other routes (Torres Strait and Suez respectively), with the assembly rejecting a provisional contract by thirty-five votes to fifteen. ${ }^{57}$ The colonial press in South Australia and Tasmania also felt the Pacific connection would 'injuriously affect' them in offering a slower mail service than via Suez. ${ }^{58}$ There was concern also about American influence, the Governor of Victoria observing to the Secretary of State for the Colonies that Webb had championed investments in the route to the US Senate on the grounds of its naval and commercial advantages for that country. ${ }^{59}$

As against such defensive concerns, the 'large and federal view' that Parkes urged underlined how, beyond individual colonial priorities, some felt that a direct San Francisco connection held the potential to change Australia's position in the world. This did not necessarily entail risking the Suez connection. On the contrary, the Suez and Pacific routes would together 'form a grand highway round the world', in which Australia would be a 'midway resting place' welcoming a 'constant stream of visitors belonging to the intellectual and 
educated classes' from both the Old and New World. ${ }^{60}$ A Pacific option would also offer Australia leverage to deepen imperial ties, notably by inducing the $\mathrm{P} \& \mathrm{O}$ 'to put out exertions' in its Suez operations, 'which they would not do if they were not disturbed by competition'. 61 In this perspective, with steamer routes stretching in both directions, Australia would hold the empire and the oceans in balance.

For a time this scenario seemed to come true for the circulation of news. Until 1872 Australia remained 'unwired' by cable telegraph which terminated in Point de Galle (Ceylon) and San Francisco. Australia relied on ships to carry the cable news from Galle. A transpacific route now linked it to the cable terminus at San Francisco (connected to New York from 1861, with a transatlantic connection from 1866). Californian newspaper owners immediately spotted a business opportunity to relay news to Australia in the form of a paper expressly for Australasian readers (modelled on rival imperial steamship newspapers), printed to time with the monthly departure of vessels for Sydney. The News of the World hoped to foster closer commercial and cultural ties between Australia and America, and promote 'mutual fellow-feeling, sympathy and friendship'. It had the potential besides to promote American news, ideas and influences in Australia and New Zealand. But as its ambitious name captures, and as communications historian Peter Putnis has shown, the News of the World envisaged not merely connecting Australia and the US west coast, but also to open a new, speedier and 'more complete' channel of communication between Australia and the wider world. ${ }^{62}$

This venture, however, lasted only two years. The Pacific route proved too unreliable to be able to consistently deliver world news first. Colonists expressed distaste for American bias in reporting on European events, notably the 'utterly unreliable' telegrams during the Franco-Prussian war. ${ }^{63}$ Furthermore, the paper's editors were often 'out of step with mainstream public opinion', liable to make too much of an imagined republican sentiment in 
the colonies. ${ }^{64}$ The paper's life was also cut short by new telegraphic connections linking Darwin to Java and London by 1872 . Steamships and the telegraph began to follow parallel tracks. The 'Eastern' route now monopolised telegraphic news to Australia, which also reinforced the imperial connection. ${ }^{65}$ Britain's sensitivity to new centres of regional influence displacing or marginalising London as a hub of power and information slowed the introduction of the cable across the Pacific, which was not 'wired' until an 'all British' cable between Vancouver and Sydney opened in 1902, and America's Pacific cable extended to the Philippines in $1904 .^{66}$

\section{'A living means of communication', 1875-90}

The rise of the telegraph did not displace the steamship's importance, with ships still vital for the carriage of mail, newspapers, books and letters, as well as passengers and certain classes of freight. After the existing Suez contract with P\&O expired, Victoria ousted NSW in contracting as the new terminus of that service. An 1873 intercolonial conference could not resolve the dispute, and NSW and New Zealand ultimately accepted the necessity of combining to support a San Francisco route. A more reliable transpacific connection was eventually achieved from 1875 through a contract with the Pacific Mail Steamship Company of New York, which boasted three decades' experience in shipping from San Francisco to Panama and Asia. A modified contract in 1877 removed the call at Kadavu in southern Fiji, which being too far from the seat of administration in Levuka, was unsatisfactory to the officials of the new British colony. The annual subsidy was $£ 72,500$ of which NSW contributed the bigger share $(£ 40,000)$, even as it soon regained from Victoria more favourable mail terms via Suez. The other Australian colonies contributed to the Pacific route on the basis of the weight of mail carried, while New Zealand, which benefitted most from the service, contributed $£ 32,500$ towards the subsidy. ${ }^{67}$ 
The Pacific route's prospects relied on trade. Trade between Australia and California expanded fivefold between 1871 and 1890, but this growth was slower than hoped and marked by considerable fluctuation. ${ }^{68}$ Besides sailing ships remained important for many categories of cargo, and sail greatly outnumbered steamship tonnage plying between Australia and the US in this period. There was always high colonial demand for 'notions', small lightweight items for household use supplied by the centres of manufacture in the east. California traded without competition in produce, notably salmon, fruit, hops and nuts. ${ }^{69}$ Overall the US exported to Australia over 150 items, while the latter's exports to the US mainly consisted of coal, opium, tin, and hides. ${ }^{70}$ Australian wool exporters eyed the US, which was closer than Europe, as a significant market, but faced high tariff barriers.

Parkes travelled to the United States in 1882 in an effort to bring imagined and material geographies of affinity into closer alignment. The trip's main aims were to promote trade, seek a reduction in wool tariffs and encourage the American subsidisation of the shipping line. It had the support of all the colonies except Victoria, a protectionist colony which did not perceive it as an opportune time to push for freer trade. But more was invested in Parkes's mission than merely trade. At least in Australia it was tied to the envisioning of a global community, the 'English-speaking race', into 'a national vitality which seems to exceed that attained by any communities in the whole range of history'. ${ }^{71}$ Reporting on Parkes' speech to the Lotus Club, where he declared 'I am one of those who thoroughly believe in the Anglo-Saxon race', the New York correspondent for the Melbourne Argus noted that despite a lack of political traction, Parkes would leave 'a very agreeable impression as the representative of Australian statesmanship, and, if I may be allowed to say so, Australian manhood'. ${ }^{72}$ Such gendered performativity and related appraisals were defining features of these transpacific encounters. As Marilyn Lake has charted, the Victorian parliamentarian Alfred Deakin, who bristled against colonial dependency and British race 
patriotism, was deeply enamoured by the perceived exemplars of powerful republican manhood he encountered on his travels through America in 1885, impressions that would inform his commitment to federation. ${ }^{73}$

Parkes' overtures sparked some anxiety in Britain, a signal that Australia was potentially striking out independently in the Pacific. Canada's long-standing trade negotiations with America were little cause for alarm, for Ottawa appeared to act 'as the intermediary of the Imperial authority'. Australia's approach, by contrast, made Britain conscious of the colonies' 'separate existence and tendencies', particularly as the Pacific was 'a new world, spacious, rich, and secure, and fast being peopled' ${ }^{74}$ Others welcomed a future Pacific detached or insulated from British influence. The Harvard philosopher Josiah Royce, after meeting with Deakin in Australia in 1888, mapped out a division between the Indian and Pacific worlds. With echoes of Parkes three decades earlier, he predicted that Britain's interests in Asia and Australia's in the Pacific would ultimately diverge, opening up to Australia a fresh field of endeavour to be shared with the United States as a 'sister republic' and 'co-worker'. 75

Great Britain's triangular presence in this transpacific sphere might be invoked in order to temper it, but it could also inspire new imperial visions. Transpacific exchanges also fostered fantasies of the "establishment of a joint protectorate over the Pacific Ocean by England and America', as Pacific Mail celebrated in its promotional material, continuing, not entirely disinterestedly, that this offered the Australasian colonies new visibility on the world stage: 'England and America and Australia. Tria juncta in uno should not be merely a dream of the enthusiast, but a practical measure for their mutual progress and for the peace of the world' ${ }^{76}$ The ideals of shared cultural and imperial capacities that would underpin an AngloAmerican alliance thus also set a course for Australia to see itself equally as an autonomous white nation, shaping visions of the Pacific and its position and role within it. ${ }^{77}$ 
Pacific Mail did not re-tender for the renewal of the service when its contract expired in 1885. It faced aggressive competition in the trades between Hawai' $i$ and California from the Oceanic Steamship Company of San Francisco, and tensions spilled into its transpacific operations. ${ }^{78}$ Oceanic assumed the running of the San Francisco-Sydney service in combination with the Union Steam Ship Company of New Zealand. This three-year contract expired in 1888, and colonies awarded only annual renewals from this point because of the possibility of a new service between Sydney and Vancouver. With the vast improvements in speed achieved meanwhile in the Indian Ocean trades, four of the Australian colonies, including NSW, joined Britain to support a weekly mail via Suez. For its part Queensland subsidised a service via Torres Strait. This left the San Francisco route redundant now to NSW as a mail service, yet the colony was 'still anxious for its maintenance', as Parkes stressed to the New Zealand Premier in 1887, but hoped for significant improvements in speed. ${ }^{79}$ Without contract commitments of at least five years, companies could not embark on shipbuilding programs to achieve this. The contract burden fell largely to New Zealand, and in 1890 NSW ceased subsidising the route, basing its contribution as the other colonies did, on the weight of mail carried. ${ }^{80}$

The Pacific steam route was perhaps of most import for facilitating first-hand contact between colonists, a 'living means of communication' as that which 'neither letters, nor papers, nor books could supply'. ${ }^{81}$ Even in light of poor mail and trade returns by 1885 , the Sydney Morning Herald believed that the American connection 'has been a boon to all the colonies' and 'a convenience to a large section of the travelling public'. ${ }^{82}$ The colonial press published a growing number of transpacific travel narratives. Imaginaries of Pacific exchange were not narrowed to the Sydney and San Francisco connection. For instance, Brisbane resident Walter Wilson described the Pacific route as stretching from Brisbane to New York. ${ }^{83}$ And while carriage statistics never rivalled Suez, estimates suggest that by 1890 the 
monthly steamer brought on average to San Francisco 200 saloon and 150 steerage passengers. $^{84}$

A new constellation of transpacific exchange followed the completion of the Canadian Pacific Rail to Vancouver in 1885. An 'All Red' bridge from Vancouver to Sydney expressed an imperial ambition to 'gird the earth' with a communications network controlled by Britain and connecting British territories. Some justifications for this route cast the US emerging as a competing actor and potential threat. For the Sydney Morning Herald, it was only 'natural' for Australian settlers to prefer connecting with their 'fellow-colonists' over 'foreigners, who, under conceivable conditions, might become our enemies'. ${ }^{85}$ Yet to others such as South Australia's Advertiser, the San Francisco route remained 'desirable' - a journey across the United States far surpassed Canada's 'trackless desert' in educational value - and of continued strategic importance to Australia. ${ }^{86}$ Even in NSW the US connection was justified by some on grounds that the people of the United States were of 'purer Anglo Saxon blood' than Canadians, while Parkes, in supporting a NSW subsidy for the Vancouver line which opened in 1893, nevertheless insisted that only the US, with its 'fine' and 'wonderful' cities, could instruct Australians on what 'population is doing in the new world'. 87

Steamship routes unsettled settler colonial frontiers, expanding them across the Pacific and reshaping Australia's sense of its Pacific locations and destinies. They also unsettled settler colonial allegiances by nudging imperial loyalties, racial affinities, and commercial prospects out of alignment. These processes, which would play out in the following decades, were already discernibly underway by the second half of the nineteenth century. ${ }^{88}$

\section{Conclusion}


'The distinctive value of the sea', the American geographer Ellen Semple remarked in 1908, 'is that it promotes many-sided relations as opposed to the one-sided relation of the land' ${ }^{89}$ For nations as well as regions, these relations and their spaces and meanings have varied with time and opportunity. ${ }^{90}$ Lying, as it were, at the crossroads of oceans, Australia's many sidedrelations and their mutual interactions are liable to be overlooked when oceans are viewed only in fragments rather than also expanses within and across which colonies and nations might relate. To foreground the latter is not necessarily to neglect Australia's Asian, island, or local Pacific contexts, or privilege high politics and commerce at the expense of local relationships and connections. It is, rather, to complicate and enrich the latter with perspectives deriving from broader spatial, cultural and political frames.

The locational advantages of different colonial settlements and their transoceanic extensions became the focus of new advocacy, contestation and debate from mid-century with the rise of steam and the prospect of routine, scheduled connections within the empire and to the wider world. Steam altered attitudes towards the feasibility and desirability of transpacific connectivities, and brought new prominence to the Pacific-oriented relations of Australia's eastern seaboard and NSW in particular. A transpacific network appealed as one leg of an imperial trunk route between Australia and Great Britain. But unlike the parallel routes across the Indian Ocean, this bridge was more distant from metropolitan-centred concerns and preoccupation with imperial possessions in Asia, while at the same time affording 'white' Australia autonomy to explore and establish racial and cultural affinities across the Pacific, and in due course a foundation for its expansive geopolitical ambitions.

It has been noted that 'it was not similar environments or coincidental transport links, but similar class aspirations and political economies' that brought Australia and California closer together. ${ }^{91}$ The expectations, debates and negotiations traced in this article suggest that steamship routes were not merely a matter of transport links coincidental or otherwise. They 
also reflected or reinforced ideological beliefs, sensibilities, and promises. Cultural and political affinities and solidarities with the United States (and later with Canada), anticipated by the early, rather messy, indeterminate and fractured history of colonial steam, would come to define and advance Australia's sense of itself as a white nation in a multiracial empire and located in a multiracial island geography, not isolated but connected to a wider, transpacific Anglo world.

Research for this article was supported by the Australian Research Council (project DE120101731). Jeannine Baker and Helen Bones provided valuable research assistance. I would like to acknowledge Marilyn Lake for facilitating the symposium 'Writing the Pacific, Rewriting Australia' at the University of Melbourne and for her comments on previous drafts. Julia Martínez also provided helpful feedback. My thanks also to the journal's anonymous reviewers for their constructive and stimulating comments, questions and suggestions. Finally, I am grateful to the journal's editors for their comments and assistance.

${ }^{1}$ Cindy McCreery and Kirsten McKenzie, 'The Australian Colonies in a Maritime World', in The Cambridge History of Australia, eds Alison Bashford and Stuart Macintyre (Melbourne: Cambridge University Press, 2013), 584.

2 'Panama Steam Route to Australia and the Pacific Trade', Sydney Morning Herald, 23 February 1854, 3.

${ }^{3}$ Penelope Edmonds, “I followed England round the world”: The Rise of Trans-imperial Anglo-Saxon Exceptionalism and the Spatial Narratives of Nineteenth-century British Settler Colonies of the Pacific Rim', in Re-Orienting Whiteness, eds Leigh Boucher, Jane Carey and Katherine Ellinghaus (New York: Palgrave, 2009), 102. 
${ }^{4}$ Marilyn Lake and Henry Reynolds, Drawing the Global Colour Line: White Men's Countries and the Question of Racial Equality (Melbourne: Melbourne University Press, 2008).

${ }^{5}$ Questions of divergent perspectives and locations have been raised in different ways by John Mateer, 'Australia is not an Island', Meanjin 65, no. 1 (2005): 89-93; Tony Ballantyne, ‘Mobility, Empire, Colonisation', History Australia 11, no. 2 (2014): 18.

${ }^{6}$ Keith Sinclair, 'Australasian Inter-Governmental Negotiations, 1865-80: Ocean Mails and Tariffs', Australian Journal of Politics and History 6, no. 2 (1970): 151-76. See also Raewyn Dalziel, “"Misunderstandings Rather than Agreements": Intercolonial Negotiations, 18671883', in Tasman Relations: New Zealand and Australia, 1788-1988, ed. Keith Sinclair (Auckland: Auckland University Press, 1987), 71-89.

${ }^{7}$ Kate Hunter, Review of Remaking the Tasman World in New Zealand Journal of History 43, no. 2 (2009): 217; Damon Salesa, 'Opposite Footers', in The Atlantic World in the Antipodes: Effects and Transformations since the Eighteenth Century, ed. Kate Fullagar (Newcastle-upon-Tyne: Cambridge Scholars Publishing, 2012), 295.

${ }^{8}$ Frances Steel, 'The "Missing Link": Space, Race and Transoceanic Ties in the SettlerColonial Pacific', in Transfers: Interdisciplinary Journal of Mobility Studies (in press).

${ }^{9}$ S.H. Roberts, Foreword to Gordon Greenwood, Early American-Australian Relations: From the Arrival of the Spaniards in America to the close of 1830 (Melbourne: Melbourne University Press, 1944), vi.

${ }^{10}$ Norman Harper, Australia and the United States (Melbourne: Thomas Nelson, 1971); Norman Bartlett, 1776-1976: Australia and America through 200 years (Sydney: Ure Smith, 1976); L.G. Churchward, Australia \& America, 1788-1972 An Alternative History (Sydney: APCOL, 1979); Norman Harper, A Great and Powerful Friend: A Study of Australian 
American Relations between 1900 and 1975 (Brisbane: University of Queensland Press, 1987).

${ }^{11}$ J.W. Davidson, 'Problems of Pacific History', Journal of Pacific History 1, no. 1 (1966):

10.

${ }^{12}$ Oskar H.K. Spate, The Spanish Lake (Canberra: Australian National University Press, 1979); Monopolists and Freebooters (Canberra: Australian National University Press, 1983); Paradise Found and Lost (Sydney: Australian National University Press, 1988).

${ }^{13}$ John Carlos Rowe, ‘Transpacific Studies and the Cultures of U.S. Imperialism', in Transpacific Studies: Framing an Emerging Field, eds Janet Hoskins and Viet Thanh Nguyen (Honolulu: University of Hawai 'i Press, 2014), 138-40. Select titles include: Bruce Cumings, Dominion from Sea to Sea: Pacific Ascendancy and American Power (New Haven: Yale University Press, 2009); Arthur Power Dudden, ed., American Empire in the Pacific: From Trade to Strategic Balance, 1700-1922 (Aldershot: Ashgate, 2004); John Curtis Perry, Facing West: Americans and the Opening of the Pacific (Westport, Conn.: Praeger, 1994); David M. Pletcher, The Diplomacy of Involvement: American Economic Expansion Across the Pacific (Columbia: University of Missouri Press, 2001).

${ }^{14}$ Arif Dirlik, ed., What is in a Rim? Critical Perspectives on the Pacific Region Idea (Lanham, MD: Rowman and Littlefield, 1998).

${ }^{15}$ Weiqiang Lin and Brenda S.A. Yeoh, 'Transpacific Studies: The View from Asia', in Transpacific Studies, 42, 54.

${ }^{16}$ Hoskins and Nguyen, 'Introduction: Transpacific Studies: Critical Perspectives on an Emerging Field', in Transpacific Studies, 3.

${ }^{17}$ Lon Kurashige, Madeline Y. Hsu and Yujin Yaguchi, 'Introduction: Conversations on Transpacific History', Pacific Historical Review 83, no. 2 (2014): 187. 
${ }^{18}$ Kornel Chang, Pacific Connections: The Making of the US-Canadian Borderlands

(Berkeley: University of California Press, 2012), 4, 16.

${ }^{19}$ Henry Yu, 'The Rhythms of the Transpacific', in Connecting Seas and Connected Ocean Rims: Indian, Atlantic, and Pacific Oceans and China Seas Migrations from the 1830s to the 1930s, eds, Donna B. Gabaccia and Dirk Hoerder (Leiden and Boston: Brill, 2011), 392, 406. For work on empire travel writers in the Pacific see Edmonds, and Lydia Wevers, Country of Writing: Travel Writing and New Zealand, 1809-1900 (Auckland: Auckland University Press, 2002), esp. ch 5.

${ }^{20}$ Adam McKeown, 'Movement', in Pacific Histories: Ocean, Land and People, eds, David Armitage and Alison Bashford (Houndsmills: Palgrave Macmillan, 2014), 159.

${ }^{21}$ See chapters by McKeown, Akira Iriye and Kaoru Sugihara in Pacific Histories.

${ }^{22}$ Matt Matsuda, Pacific Worlds: A History of Seas, Peoples, and Cultures (Cambridge: Cambridge University Press, 2012), 6.

${ }^{23}$ Adam Bogue, Steam to Australia: Its General Advantages Considered (Sydney: W. and F. Ford, 1848), 16, 17 (emphasis in original). Thanks to Cameron White for bringing this document to my attention.

${ }^{24}$ Ruth Mandujano López, 'From Sail to Steam: Coastal Mexico and the Reconfiguration of the Pacific in the Nineteenth Century', International Journal of Maritime History 22, no. 2 (2010): 260; Raymond Rydell, Cape Horn to the Pacific: The Rise and Decline of an Ocean Highway (Berkeley: University of California Press, 1952).

25 'Panama Steam Route to Australia and the Pacific Trade', Sydney Morning Herald, 23 February 1854, 3.

${ }^{26}$ John Bach, A Maritime History of Australia (Melbourne: Nelson, 1976), 114. 
${ }^{27}$ Sydney Morning Herald, 20 October 1854, 5 and 24 October 1854, 4; Henry Hussey, The Australian Colonies Together with Notes of a Voyage from Australia to Panama in the 'Golden Age’ (London: Blackburn \& Burt, 1855).

28 'Parliament of New South Wales Legislative Assembly, Friday, 6 August 1858: Steam Communication between Sydney and Panama', Empire, 10 August 1858, 6.

${ }^{29}$ Ibid.

${ }^{30}$ Britain's disengagement stemmed from Post Office official Rowland Hill, who argued, amongst other things, that the development of telegraphs favoured the Suez route. Minute of 1858, reprinted in Sydney Morning Herald, 16 April 1864, 5.

${ }^{31}$ Valeska Huber, Channelling Mobilities: Migration and Globalisation in the Suez Canal Region and Beyond, 1869-1914 (Cambridge: Cambridge University Press, 2013), 37, 55; Tony Ballantyne and Antoinette Burton, 'Empires and the Reach of the Global', in A World Connecting, 1870-1945, ed. Emily S. Rosenberg (Cambridge: The Belknap Press, 2012), 357.

32 'Steam Communication with Australia', New York Herald reprinted in Daily Alta California, 4 February 1870.

${ }^{33}$ Daily Alta California, 26 January 1870, 2.

${ }^{34}$ For example, 14 August 1866, New Zealand Post Office: History - Mails: Ocean Mail Services, AAME W5603 8106, Box 70, National Archives of New Zealand.

35 'The Austral-American Mail Service', South Australian Register, 3 February 1870, 4.

${ }^{36}$ Empire, 26 January 1870, 2.

37 'California and the Pacific Railway', Illustrated Sydney News, 30 January 1874, 6.

${ }^{38}$ Erika Esau, Images of the Pacific Rim: Australia and California 1850-1935 (Sydney: Power Publications, 2010). 
${ }^{39}$ Ian Tyrrell, True Gardens of the Gods: Californian-Australian Environmental Reform, 1860-1930 (Berkeley: University of California Press, 1999), 6.

${ }^{40}$ Matthew Wittman, 'Empire of Culture: U.S. Entertainers and the Making of the Pacific Circuit, 1850-1890' (PhD thesis, University of Michigan, 2010).

41 'Trade with Australia', Empire [from the Panama Star], 10 September 1867, 2.

${ }^{42}$ L.G. Churchward, 'Australian-American Relations during the Gold Rush', Historical Studies: Australia and New Zealand 2, no. 5 (1942): 23-4.

43 'The Austral-American Mail Service', South Australian Register, 3 February 1870, 4; 'The Pacific Mail Route', South Australia Register, 17 January 1870, 5; Mercury, 7 February $1870,2$.

44 'The Pacific Mail Route', South Australia Register, 1 February 1870, 3, 'Steam Communication with England via California', Queenslander, 8 January 1870, 2. For rim-state engagement in Fiji prior to British annexation in 1874, see Roger Thompson, Australian Imperialism in the Pacific: The Expansionist Era, 1820-1920 (Melbourne: Melbourne University Press, 1980), 21-34.

${ }^{45}$ Ian Tyrrell, Transnational Nation: United States History in Global Perspective since 1789 (Basingstoke: Palgrave Macmillan, 2007), 112-14.

${ }^{46}$ For example, Julius Vogel to Saul Samuel, 4 June 1873, Papers relating to Ocean Mail Communication (Sydney: Government Printer, 1873), 36; Sydney Morning Herald, 6 April 1875, 6; Brisbane Courier, 31 January 1870, 2.

${ }^{47}$ Town and Country Journal, 14 February 1874, 10.

${ }^{48}$ South Australia Register, 17 January 1870, 5.

${ }^{49}$ James Belich, Replenishing the Earth: The Settler Revolution and the Rise of the AngloWorld, 1783-1939 (Oxford: Oxford University Press, 2009), ch. 9.

${ }^{50}$ Australasian, 2 July 1870, 16. 
${ }^{51}$ Brisbane Courier, 22 January 1870, 3.

52 'Mr Parkes and the Californian Mail Service', Queenslander, 1 July 1871, 10. See also, South Australian Chronicle, 27 May 1871, 12.

${ }^{53}$ Australasian, 29 April 1871, 17.

54 'Complimentary Dinner to Mr W.H. Webb’, Argus, 13 March 1872, 5.

${ }^{55}$ Edmonds, 107.

56 'California Mail Contract', Victoria Parliamentary Debates, Session 1872, Vol. XIV

(Melbourne: 1872), 949.

${ }^{57}$ Ibid, 966; L.G. Churchward, 'American Enterprise and the Foundation of the Pacific Mail Service', Historical Studies: Australia and New Zealand 3, no. 11 (1945): 217-24.

${ }^{58}$ Mercury, 15 January 1870, 2; 7 February 1870, 2.

${ }^{59}$ Sinclair, 'Australasian Inter-Governmental Negotiations', 164.

${ }^{60}$ South Australian Register, 15 May 1871, 5; 'Mr Parkes and the Californian Mail Service', Queenslander, 1 July 1871, 10.

61 'The Sydney and Californian Mail Service', South Australian Chronicle, 27 May 1871, 12. This did result in improvements to ships and faster speeds via Suez, T.A. Coghlan, $A$ Statistical Account of the Seven Colonies of Australasia (Sydney: Government Printer, 1893), 88.

${ }^{62}$ Peter Putnis, 'Shipping the Latest News across the Pacific in the 1870s: California's News of the World', American Journalism 30, no. 2 (2013): 235-59 (quote is from 243).

${ }^{63}$ Peter Putnis, 'Overseas News in the Australian Press and the Colonial Experience of the Franco-Prussian War', History Australia 4, no. 1 (2007): 06.1-06.19. For one dismissal of war cables, see West Coast Times, 22 December 1870, 2.

${ }^{64}$ Putnis, 'Shipping the Latest News', 252.

${ }^{65}$ Putnis, 'Overseas News in the Australian Press', 06.13. 
${ }^{66}$ Robert W.D. Boyce, 'Imperial Dreams and National Realities: Britain, Canada and the Struggle for a Pacific Telegraph Cable, 1879-1902', English Historical Review 115, no.460 (2000): 39-70; Simone Müller-Pohl, 'Wiring the Pacific: North American Perspectives on a (De)Colonial Project', in Provincializing the United States: Colonialism, Decolonization, and (post)colonial Governance in Transnational Perspective, eds Eva Bischoff, Norbert Finzsch and Ursula Lehmkuhl (Heidelberg: Winter, 2014), 155-80.

67 'The Postmaster-General's Report', Sydney Morning Herald, 17 May 1881, 3.

${ }^{68}$ New South Wales Statistical Register (Sydney: 1890), 175; Tyrrell, True Gardens, 34;

Churchward, 'American Enterprise', 224.

69 'Australian Trade with America', San Francisco Chronicle, reprinted in Bowral Free Press, 25 April 1888, 2.

${ }^{70}$ Sacramento Daily Union, 17 April 1888, 1.

71 'Sir Henry Parkes’ Mission’, Queenslander, 14 January 1882, 48.

72 'Sir Henry Parkes in the United States', Argus, 13 April 1882, 4.

${ }^{73}$ Marilyn Lake, “"The Brightness of Eyes and Quiet Assurance which Seem to Say American": Alfred Deakin's Identification with Republican Manhood', Australian Historical Studies 38, no. 129 (2007): 32-51.

${ }^{74}$ Argus (reporting on an article in The Times), 24 March 1882, 4.

${ }^{75}$ Lake, 'The Brightness of Eyes', 42-3.

${ }^{76}$ Pacific Mail Steamship Company, Handbook of Information for Passengers and Shippers (Sydney: Geo Loxon and Co, 1883), 21. For more on this 'triangularity', see Paul Giles, Antipodean America: Australasia and the Constitution of U.S. Literature (Oxford: Oxford University Press, 2013). 
${ }^{77}$ Paul A. Kramer, 'Empires, Exceptions, and Anglo-Saxons: Race and Rule between the British and United States Empires, 1880-1910', Journal of American History 88, no. 4 (2002): 1315-53; Lake, 'The Brightness of Eyes'.

${ }^{78}$ Jacob Adler, 'The Oceanic Steamship Company: A Link in Claus Spreckels' Hawaiian Sugar Empire', Pacific Historical Review 29, no. 3 (1960): 257-69.

79 'Pacific Mail Services', Appendices to the Journals of the House of Representatives F-4 (Wellington: 1888), 23.

${ }^{80}$ This amounted to $£ 4,000$ annually (the previous subsidy was $£ 37,000$ of which NSW paid $£ 25,750$ and NZ $£ 11,250)$.

${ }^{81}$ South Australian Chronicle, 27 May 1871, 12.

${ }^{82}$ Sydney Morning Herald, 16 July 1885, 7.

${ }^{83}$ Walter Horatio Wilson, The Pacific Route: Brisbane to New York (Brisbane: Gordon and Gotch, 1884).

${ }^{84}$ Daily Alta, 1 January 1891, 9.

${ }^{85}$ Sydney Morning Herald, 11 March 1889, 6.

${ }^{86}$ Advertiser, 8 October 1889, 4.

${ }^{87}$ New South Wales Parliamentary Debates, Fifteenth Parliament, Session 1892-93, Vol. 66 (Sydney, 1893), 8195, 8188.

${ }^{88}$ Steel, "The "Missing Link"'.

${ }^{89}$ Ellen Churchill Semple, 'Oceans and Enclosed Seas: A Study in Anthropo-Geography', Bulletin of the American Geographical Society 40, no. 4 (1908): 195.

${ }^{90}$ G. Balachandran, 'Sovereignty, Subjectivities, Narrations: Nations and Other Stories from the Sea', International Journal of Maritime History 21, no. 2 (2009): 16-20.

${ }^{91}$ Tyrrell, True Gardens, 35. 